\title{
EVALUASI PEMILIHAN PENYEDIA JASA KURIR BERDASARKAN METODE ANALYTICAL HIERARCHY PROCESS (AHP)
}

\author{
Juli Astuti' ${ }^{1)}$, Erika Fatma ${ }^{2}$ \\ ${ }^{1,2)}$ Program Studi Manajemen Logistik Industri Elektronika Politeknik APP Jakarta \\ ${ }^{*}$ Penulis korespondensi : rika-fatma@kemenperin.go.id \\ DOI Number : $10.30988 /$ jmil.v1i1.5
}

\begin{abstract}
Logistics activity plays an important role in the business process where there is a distribution process to deliver product from the manufacturer / seller to the consumer. Nowadays there are many companies that provide logistics services with its own advantages and disadvantages. This condition, gives users more flexibility in determining which courier companies they will use. IN ordr to aid decision makers in selecting the best courier services providers, we conducted a study regarding the criteria used in determining user's choice by using Analytical Hierarchy Process (AHP). The purpose of this study was to determine the main criteria as user's consideration for selecting the best logistics service providers. Based on a survey conducted on the online sellers, it is known that the criteria of the key considerations in selecting a courier service is Reliability, the reliability of a courier company in serving the needs and desires of its customers, followed by cost and convenience.
\end{abstract}

Keywords: Courir services provider, Analytical Hierarchy Process

\begin{abstract}
Abstrak
Aktivitas logistik memegang peranan penting dalam proses bisnis dimana terdapat proses distribusi untuk menyalurkan produk dari produsen/penjual kepada konsumen. Saat ini bermunculan semakin banyak perusahaan yang bergerak di bidang penyediaan pelayanan jasa logistik, dengan berbagai kelebihan dan kekurangannya. Kondisi ini membuat pengguna jasa lebih leluasa dalam menentukan pilihan, perusahaan kurir mana yang dipercaya untuk mengambil alih sebagian fungsi bisnisnya.Untuk membantu pengambilan keputusan dalam pemilihan penyedia jasa kurir, penulis melakukan penelitian mengenai kriteria yang digunakan pengguna jasa dalam menentukan penyedia jasa terbaik. Penelitian dilakukan menggunakan metode Analytical Hierarchy Process (AHP), metode AHP dipilih karena metode ini dapat membuat sebuah kerangka pengambilan keputusan dengan efektif atas persoalan yang kompleks. Permasalahan yang terdiri atas beberapa pertimbangan, kemudian disederhanakan ke dalam beberapa kriteria yang kemudian disusunan dalam suatu hirarki.Setelah disusun dalam hierarki dapatditentukan criteria terpenting yang menjadi pertimbangan utama pengguna jasa. Penelitian ini dibatasi pada perusahaan penyedia jasa logistik yang bergerak pada jasa pengiriman ekspres (kurir). Reponden dibatasi pada pengguna yang menggunakan jasa pengantaran barang (kurir) untuk keperluan penjualan online. Tujuan penelitian ini adalah untuk mengetahui kriteria utama yang diprioritaskan sebagai pertimbangan bagi pengguna jasa dalam pemilihan penyedia jasa logistik. Berdasarkan survey yang dilakukan terhadap para penjual online, diketahui bahwa kriteria yang menjadi pertimbangan utama dalam pemilihan jasa kurir adalah Reliability, yaitu keandalan suatu perusahaan jasa kurir dalam melayani kebutuhan dan keinginan pelanggannya diikuti dengan cost (biaya pengiriman) dan Convinience (kenyamanan).
\end{abstract}

Kata kunci: Penyedia jasa Kurir, Analytical Hierarchy Process 


\section{PENDAHULUAN}

Aktivitas logistik memegang peranan penting dalam proses bisnis dan perdagangan dimana terdapat proses distribusi untuk menyalurkan barang/produk dari produsen/penjual kepada konsumen. Permasalahan dalam distribusi mencakup kemudahan untuk mendapatkan produk kapanpun dan dimanapun dengan tepat waktu dan biaya yang sesuai. Dalam pelaksanaan kegiatan logistik, para pemilik barang cenderung untuk melakukan praktek alih daya (outsource) kepada pihak lain yang menyediakan jasa logistik (logistic service provider) untuk menangani urusan logistik perusahaan inti seperti pergudangan, pengiriman bahan baku / produk, dan pengemasan (Falsini, dkk, 2012). Untuk memenuhi kebutuhan pengiriman barang, saat ini banyak lahir perusahaan jasa kurir yang terus berkembang dan bersaing untuk merebut pasar. Proses distribusi dan pengantaran barang merupakan bisnis inti bagi perusahaan ekspedisi jasa pengangkutan barang/jasa kurir tersebut.

Perkembangan pelayanan jasa logistik, yang sedang berkembang pesat adalah pelayanan jasa kurir. Bisnis ini menunjukkan perkembangan yang pesat. Salah satu faktor penyebab perkembangan tersebut adalah pertumbuhan bisnis online khususnya pada sektor konsumsi. Berdasarkan laporan tahunan PT. Kereta Api Logistik (2014), pada tahun 2013, JNE memegang market share terbesar dengan pangsa pasar sekitar $13 \%$. Disusul oleh TIKI dan PT Pos Indonesia, dengan nilai total pasar untuk bisnis kurir diperkirakan mencapai 8.6 hingga 9 triliun rupiah per tahunnya. Nilai ini meningkat sekitar $8.1 \%$ dibandingkan dengan tahun sebelumnya.

Tantangan terbesar bagi perusahaan penyedia jasa kurir adalah bagaimana cara bersaing dengan perusahaan lain yang menawarkan jenis jasa yang sama, dan pengguna layanan semakin menuntut keamanan dan kehandalan pelayanan pengirim barang. Meningkatnya persaingan antar perusahaan jasa, memaksa penyedia layanan untuk meningkatkan kinerjanya dengan berupaya memahami ekspektasi pengguna layanan. Secara terperinci, Chan, et.al., (2006) mengusulkan pengukuran benchmarking terhadap berbgai aspek, seperti keandalan, memimpin waktu, kenyamanan, fleksibilitas, biaya, return on assets, hubungan, inovasi, perbaikan, biaya, waktu, kemampuan, integrasi dengan sistem yang ada, kemauan, dan kendala. Dalam hal ini, dapat dikatakan bahwa kunci keberhasilan dan daya saing pada bisnis jasa kurir adalah tentang bagaimana menghemat waktu proses distribusi. Selain itu, jaminan kualitas pelayanan dan kepuasan pelanggan dalam rangka untuk menarik pelanggan terkait dengan layanan disediakan oleh perusahaan.

Banyaknya perusahaan yang menyediakan pelayanan jasa logistik dengan berbagai kelebihan dan kekuranganya, membuat pengguna jasa lebih leluasa dalam menentukan pilihan perusahaan logistik mana yang dipercaya untuk mengambil alih sebagian fungsi bisnisnya. Dalam proses pengambilan keputusan, pelanggan akan dihadapkan pada 
berbagaialternatif yang dapat dipilih, sehingga untuk suatu permasalahan beberapa pembuat keputusan dapat mengambil keputusan yang berbeda. Dalam dunia bisnis, proses pengambilan keputusan menjadi salah satu kunci yang mendasar dan penting seperti dalam Inventory control, pengembangan produk baru, investasi, sampai pada pemilihan supplier, dan pemilihan distributor, terutama untuk pengambilan keputusan pemilihan penyedia jasa logistik terbaik.

Untuk membantu pengambilan keputusan dalam pemilihan penyedia jasa logistik/jasa kurir, penulis melakukan penelitian mengenai evaluasi pemilihan penyedia jasa kurir, menggunakan metode AHP. Metode AHP dipilih karena metode ini dapat membuat kerangka pengambilan keputusan yang efektif atas suatu persoalan kompleks dengan menyederhanakan proses pengambilan keputusan dan memecahkan persoalan tersebut kedalam kriteria kemudian menata kriteria tersebut dalam sebuah susunan hirarki. Sehingga hasil analisis dapat mensintesis berbagai pertimbangan untuk menetapkan variabel yang mana yang memiliki prioritas paling tinggi dan bertindak untuk mempengaruhi hasil pada situasi tersebut.

Berdasarkan latar belakang diatas beberapa pertanyaan yang perlu dikaji dalam penelitian ini adalah bagaimana menentukan kriteria yang menjadi dasar keputusan pemilihan penyedia jasa logistik dan bagaimana mengembangkan model pengambilan keputusan secara sistematis dalam pemilihan penyedia jasa logistik
(LSP) berdasarkan model Analytical Hierarchy Process (AHP).

Untuk memperjelas proses analisis, diperlukan beberapa batasan untuk memperjelas lingkup penelitian yang dilakukan. Batasan masalah yang digunakan adalah sebagai berikut:Batasan dalam pelaksanaan penelitian ini pemilihan penyedia jasa kurir (LSP) di batasi pada perusahaan yang bergerak di bidang pengantaran barang (ekspedisi/kurir); Responden dibatasi pada pengguna yang menggunakan jasa pengantaran barang (kurir) ke konsumen akhir.Tujuan dalam penelitian ini adalah untuk mengetahui kriteria utama dalam pertimbangan pengguna jasa dalam pemilihan penyedia jasa logistik. Diharapkan, hasil penelitian ini dapat bermanfaat bagi perusahaan pengguna penyedia jasa logistik, sebagai alat bantu untuk memutuskan penyedia jasa logistik terbaik yang akan dipilih untuk mendukung proses bisnisnya.

\section{TINJAUAN PUSTAKA}

Logistik merupakan bagian dari supply chain management, yaitu pendekatan yang digunakan untuk mengintregasikan antara supplier, pabrik, gudang, dan retailer sehingga barang yang diproduksi dapat didistribusikan dalam jumlah, waktu, dan lokasi yang tepat untuk meminimasi biaya keseluruhan dan meningkatkan pelayanan konsumen (Chopra and Meindl, 2004). Dimana, logistik didefinisikan sebagai disiplin yang berkaitan dengan pengadaan (procurement), penyimpanan (storage), dan pengantaran barang (delivery) sesuai dengan jenis, jumlah, waktu, dan tempat yang 
dikehendaki konsumen dari titik asal ke titik tujuan. Dari definisi tersebut, maka dapat diketahui bahwa yang menjadi obyek dari logistik adalah barang, dengan berbagai aktivitas didalamnya berupa pengadaan, penyimpanan, dan pengantaran, dengan misi yang harus dicapai yaitu barang yang sesuai, waktu dan tempat yang tepat (Stock, 2001).

Menurut Chopra dan Meindl (2004) distribusi merupakan langkahlangkah yang diambil untuk memindahkan dan menyimpan produk dari tingkat pemasok ke tingkat konsumen dalam supply chain. Distribusi adalah kunci penggerak dari keseluruhan aktivitas perusahaan, karena berhubungan langsung dengan biaya supply chain, distribusi dan transportasi serta tingkat penerimaan dan kepuasan pelanggan. Pendistribusian produk merupakan faktor penting sebagai perantara sekaligus penghubung antara produsen dengan konsumen agar produk dapat diterima konsumen dengan cepat, tepat dan dalam kondisi yang sesuai yang diharapkan baik produsen maupun konsumen, perlu pengelolaan distribusi yang baik.

Berdasakan Peraturan Presiden Republik Indonesia Nomor 26 Tahun 2012, mengenai Cetak Biru Sistem Logistik Nasional, Penyedia jasa logistik Indonesia lokal umumnya fokus pada penyediaan jasa logistik dasar (basic services), atau dengan kategori Logistics Service Provider (LSP). Jasa layanan logistiknya dapat mencakup manajemen ketersediaan barang dan/atau sarana pengemasan lalu mengirimnya tepat waktu; Manfaat utama dari penyedia jasa logistik atau pengiriman kilat adalah memudahkan seseorang melakukan pengiriman barang secara tepat, cepat dan praktis kepada rekan bisnis, teman, dan kerabat serta memberi pengalaman terbaik kepada pelanggan secara konsisten. Salah satu peranan yang penting dalam kelangsungan jasa logistik atau pengiriman kilat yaitu tidak terlepas dari alat transportasi yang mendukung akan ketepatan serta kecepatan waktu adalah transportasi penerbangan dimana dari pihak penyedia jasa pengirman barang ingin memaksimalkan pelayanan serta kepuasan pemakai jasa logistik, karena transportasi penerbangan memberikan suatu kelebihan dalam hal waktu mencapai satu tujuan dibandingkan jalan darat maupun laut.Salah satu usaha yang bergerak dibidang penyedia jasa logistik adalah, jasa kurir/antaran ekspres/bisnis hantaran potongan. Bisnis BHP Kurir memiliki 3 Key success factor (KSF) yaitu brand image, jumlah outlet dan system IT. KSF merupakan suatu komponen penunjang yang harus dimiliki oleh pelaku usaha untuk dapat sukses di industri yang digeluti (Kalog, 2014).

Metode AHP adalah sebuah metode pemecahan permasalahan yang komplek/rumit dan dalam situasi yang tidak terstruktur menjadi bagianbagian yang tersusun. Mengatur bagian atau variabel ini menjadi suatu bentuk susunan hierarki, kemudian memberikan nilai numerik untuk penilaian subjektif terhadap kepentingan relatif dari setiap variabel dan mensintesis penilaian untuk variabel mana yang memiliki prioritas tertinggi yang akan mempengaruhi penyelesaian dari situasi tersebut. AHP menggabungkan pertimbangan dan 
penilaian pribadi dengan cara yang logis dan dipengaruhi imajinasi, pengalaman, dan pengetahuan untuk menyusun hierarki dari suatu masalah yang berdasarkan logika intuisi dan juga pengalaman untuk memberikan pertimbangan.Metode

AHP memproses masalah multikriteria yang kompleks menjadi suatu model hirarki. Dengan hirarki, suatu masalah yang kompleks dapat diuraikan sehingga permasalahan akan tampak lebih terstruktur dan sistematis (Guitouni dan Martel, 1998). Tingkat teratas pada hirarki adalah tujuan utama permasalahan, lalu terpecah menjadi level intermediate berupa kriteria dan subkriteria, hingga level terbawah yang berupa alternatifalternatif.

Metode AHP ini tidak rumit, mudah digunakan dan dipahami, sangat fleksibel, aplikasinya luas dan konsisten; mampu memfasilitasi komunikasi antara permasalahan dan rekomendasi solusi; menyediakan nilai yang unik untuk mengkuantitatifkan konsistensi penilaian; tidak menjadikan intuisi, pengalaman, dan pengetahuan teoritis yang menjadi domain ahli sebagai sistem pakar; tidak membutuhkan preferensi independen sebagai pelengkap;Selain itu, metode ini dapat diintegrasikan dengan metode lain seperti optimasi dan goal programming; mampu mereduksi kesalahan pembuat keputusan dengan pendekatan dekomposisi pada saat penilaian (Adriyana, 2012; Rahmadani dan Ciptomulyono, 2011).

Dalam penggunaannya, AHP sering dikombinasikan dengan metode analisis lain. Salah satunya adalah Metode Simple Additive
Weighting (SAW). Konsep dasar metode SAW adalah mencari penjumlahan terbobot dari rating kinerja pada setiap alternatif pada semua atribut. Metode SAW membutuhkan proses normalisasi matriks keputusan (X) ke suatu skala yang dapat diperbandingkan dengan semua rating alternatif yang ada (Maniya, 2010).

Penelusuran dan studi literatur terhadap penelitian-penelitian yang sebelumnya, dilakukan dasar untuk mengetahui kriteria-kriteria yang dianggap penting dalam pemilihan penyedia jasa logistik. Selain itu studi literatur juga dilakukan untuk mempelajari metode yang digunakan dalam penelitian-penelitian sebelumnya. Falsini, et.al., (2012) melakukan penelitian mengenai pemilihan penyedia jasa logistik. Penelitian ini bertujuan untuk mengembangkan model yang bertujuan untuk mengatasi keterbatasan metode AHP, dengan menggabungkan indikasi ahli 'dengan penilaian objektif yang berasal dari analisis data historis. Kinerja masa lalu pemasok digunakan untuk merevisi kesalahan sehingga diperoleh tingkat rasio konsistensi tinggi.

Penelitian dari Chan dan Chan (2006) mengenai benchmarking kinerja industri pengiriman barang (postal services) menggunakan Metode AHP. Penelitian ini dibagi ke dalam dua tahap, dengan mempertimbangkan faktor kualitatif dan kuantitatif. Tahap pertama bertujuan untuk evaluasi kinerja perusahaan yang menjadi acuan dari perusahaan pesaingnya. Tahap kedua bertujuan menemukan praktek terbaik sesuai daftar alternatif perbaikan yang 
dihasilkan pada tahap pertama. Kriteria dalam penelitian adalah: reliability, lead time, convenience, flexibility, cost, return on assets dan relationship.

Sevkli (2010), melakukan perbandingan hasil pemilihan menggunakan metose ELECTRE dan fuzzy-ELECTRE. Metode ELECTRE (ELimination Et Choix Traduisant la REalite) merupakan pemilihan dengan menghilangkan pilihan yang tersedia berdasarkan kondisi nyata. Pemilihan dilakukan dengan cara mewawancarai manajer perusahaan industri, berdasarkan kriteria: delivery performance, quality performance, price/cost, financial strength dan management/organisational strength. Hasil penelitian menunjukan bahwa kriteria tertinggi adalah delivery performance, quality performance, price/cost.

Pemilihan jasa Third party logistics (TPL), juga dilakukan oleh Sadiq, et.al., (2006). Penelitian ini membahas isu-isu kunci yang berkaitan dengan tingkat penggunaan jasa TPL, kontrak perjanjian jasa logistik yang digunakan, keuntungan bagi perusahaan pengguna,kendala yang dihadapi dalam pelaksanaan kerjasama logistik, dampak penggunaan kontrakjasa logistik pada biaya logistik, kepuasan pelanggan, dan karyawan dari perusahaan pengguna dan rencana pengguna jasa saat perbaikan kontrak logistik.

Berdasarkan literature tersebut, penulis memilih empat criteria dalam pemilihan jasa kurir yaitu: Reliability; Convinience; Service dan Cost. Dengan alternatif jasa kurir, menggunakan JNE, TIKI dan POS sebagai tiga perusahaan kurir terbesar di Indonesia.

\section{METODE PENELITIAN}

Tahapan dalam penelitian "Evaluasi pemilihan Penyedia Jasa Kurir berdasarkan metode Analytical Hierarchy Process (AHP)" terdiri atas beberapa tahapan yaitu tahap persiapan penelitian, pengumpulan dan pengolahan data, analisis, dan tahap penarikan kesimpulan. Penelitian dilakukan selama 7 bulan dari bulan April hingga bulan November 2015.

Pengambilan data responden diakukan dengan menyebarkan kuesioner secara langsung dan secara online. Pendataan kuesioner secara online dilakukan dengan mendatangi responden yang memiliki bisnis onliene di wilayah Jakarta, Bogor, Tangerang dan Depok. Sedangkan survey online dilakukan dengan menggunakan halaman layanan websurvey online, www.qualtrics.com, Layanan ini merupakan layanan survey bebas pakai.

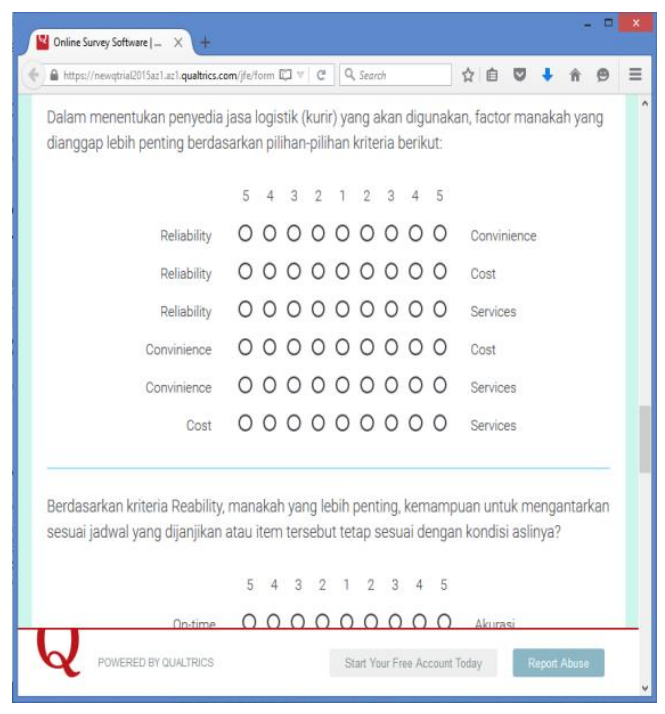

Gambar 1. Tampilan laman pendataan online website Qualtrics.com 
Berdasarkan penyebaran kuesioner secara langsung (pengisian fisik) diperoleh 25 responden dari total 30 kuesioner yang didapatkan. Sedangkan untuk survey online, tautan survey disebarkan kepada para pelaku penjual online melalui email dan melalui layanan social media lain. Responden yang digunakan dari kuesioner online sebanyak 11 responden, dari 15 responden yang mengikuti survey online. Total responden yang digunakan untuk pengolahan data adalah 36 responden. Pemilihan responden, dilakukan berdasarkan responden yang melakukan pengisian dengan lengkap dan memiliki jawaban yang konsisten.

Penetuan kriteria yang digunakan pada penelitian ini didasarkan pada penelitian Chan dan Chan (2006), yang melakukan penelitian untuk menentukan benchmarking penilaian kinerja perusahaan jasa pengiriman barang. Karena penelitian ini menggunakan objek yang sama yaitu perusahaan pengiriman barang, maka kriteria yang terpilih dalam penelitian Chan dan Chan (2006) akan dijadikan dasar dalam penentuan kriteria awal pemilihan penyedia jasa logistik. Untuk tahap pertama AHP, kriteria pemilihan penyedia jasa logistik, disusun kedalam suatu hirarki, yaitu tujuan pengambilan keputusan (Level 1), beberapa kriteria (Level 2). Gambaran mengenai hierarki permasalahan ditunjukan pada Gambar 2.

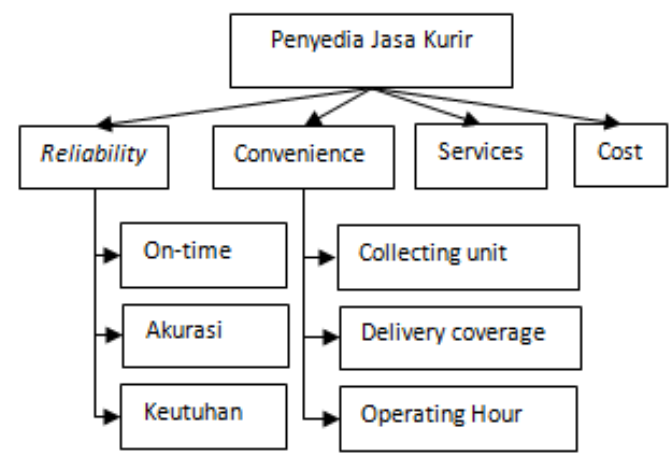

Gambar 2. Hierarki kriteria permasalahan

Kriteria dan definisi mengenai kriteria yang digunakan dalam penelitian, adalah sebagai berikut:

\section{a. Reliability}

Kemampuan untuk mengantarkan produk/ item ketujuan yang benar pada atau sebelum target atau jadwal yang dijanjikan dan item tersebut tetap sesuai dengan kondisi aslinya (tidak berubah /rusak). Kriteria ini terdiri dari sub-kriteria: On-time delivery dan Akurasi.

b. Convenience

Kemudahan pelanggan untuk memperoleh pelayanan jasa dari penyedia jasa logistik. Kriteria ini terdiri dari sub-kriteria: collecting unit, delivery coverage dan operating hour.

\section{c. Services}

Jenis layanan yang tersedia, yang disesuaikan dengan kebutuhan pelanggan.

d. Biaya pengiriman (Cost)

Biaya yang dibayarkan oleh pengguna jasa untuk memperoleh layanan jasa pengiriman.

Kriteria pada level 1, yaitu Reliability dan Convenience kemudian diturunkan menjadi kriteria-kriteria pada level dibawahnya (level 2) yang memberi penjelasan lebih rinci terhadap 
Reliability dan Convenience, Kriteria yang digunakan adalah:

a. On-time: kemampuan pengiriman barang untuk sampai tujuan tepat dengan jadwalnya

b. Akurasi: kemampuan pengiriman barang untuk tiba pada tujuan pada lokasi yang tepat

c. Keutuhan: kemampuan pengiriman barang agar barang tidak rusak atau cacat ketika tiba

d. Collecting unit: jumlah unit penerima barang (kantor layanan) yang dekat dengan konsumen

e. Coverage area: areal pengiriman yang dapat dijangaku oleh penyedia jasa

f. Operating hour: waktu operasi kantor layanan untuk proses penerimaan barang

Tahap selanjutnya adalah penentuan nilai bobot dari masingmasing kriteria yang telah ditetapkan, serta perhitungan skor untuk tiap alternative yang tersedia.

\section{HASIL DAN PEMBAHASAN Preferensi pengguna pada kriteria tingkat 1}

Tahap awal pengolahan data kuisioner adalah dengan mencari nilai perbandingan antar kriteria dengan cara memasukkan angka-angka penilaian berdasarkan data kuesioner ke dalam matriks perbandingan. Metode yang untuk penentuan preferensi digunakan ialah analisa perbandingan berpasangan (comparative judgment), prinsip ini berarti membuat penilaian tentang kepentingan relatif dua elemen pada suatu tingkat tertentu dalam kaitanya dengan tingkat di atasnya. Nilai bobot dari bobot 1 sampai dengan 9. Nilai bobot 1 menggambarkan sama penting, ini berarti atribut yang sama skalanya, nilai bobotnya 1 , sedangkan nilai bobot 9 menggambarkan kasus atribut yang penting absolut dibandingkan dengan yang lainnya. Analisa perbandingan dilakukan dalam dua tahap yaitu, analisa perbandingan pada tingkat pertama (Reliability, Convenience, Services dan Cost) dan analisa perbandingan pada tingkat kedua yaitu akurasi, ontime dan keutuhan pada Reliabity, collecting unit, coverage area dan operating hour pada Convenience.

Setelah dibuat matriks perbandingan dari masing-masing responden, kemudian data seluruh responden dikonsolidasi menggunakan rata-rata geometric mean. Geometric mean digunakan karena tiap responden berprilaku sebagai individu yang bertindak sendiri-sendiri, dan perhitungan ratarata geometris dianggap lebih konsisten untuk digunakan, dibandingkan dengan rata-rata aritmatika. Nilai perbandingan berpasangan hasil perhitungan geometric mean seluruh responden pada tingkat pertama disajikan pada Tabel 1.

Tabel 1. Matriks Perbandingan berpasangan kriteria tingkat 1

\begin{tabular}{|c|c|c|c|c|}
\hline Kriteria & Reliability & Convenience & Services & Cost \\
\hline Reliability & 1 & 2.76 & 1.8 & 1.67 \\
\hline Convenience & 0.36 & 1 & 1.18 & 0.94 \\
\hline Services & 0.56 & 0.85 & 1 & 0.74 \\
\hline Cost & 0.6 & 1.06 & 1.34 & 1 \\
\hline
\end{tabular}

Untuk mengetahui konsistensi dari hasil konsolidasi nilai perbandingan berpasangan, dilakukan perhitungan untuk mengetahui nilai eigen valuenya. Eigen Value merupakan bobot tiap elemen pada 
suatu perhitungan matriks, yang akan menjadi dasar untuk mengetahui nilai Consistency Index (CI) dan Consistensy Ratio (CR). Berdasarkan hasil perhitungan dari rasio matriks berpasangan pada Tabel 1, diperoleh nilai Eigen Value pada perbandingan berpasangan tingkat 1 sebesar 4.041.

$$
C I=\frac{(\lambda \max -\mathrm{n})}{n-1}=\frac{(4.041-4)}{3}=0.015
$$

Nilai CI kemudiasn dibandingkan dengan nilai Random Consistency (CR) yang berasal dari tabel nilai Random yang dikembangan oleh Saaty (Falsini, et. al., 2012), dimana nilai CR bergantung pada jumlah kriteria yang digunakan. Perhitungan pada tingkat pertama menggunakan empat (4) kriteria, maka nilai $\mathrm{CR}$ nya adalah tabelnya adalah 0.90 .

$$
C R=\frac{C I}{R C}=\frac{0.0802}{0.90}=0.014
$$

Nilai perhitungan $\mathrm{CR}$ adalah $1.4 \%$, hal ini menunjukan bahwa matriks perbandingan yang diperoleh memiliki tingkat konsistensi yang dapat diterima dan valid. Perhitungan dapat diterima dan dinyatakan valid, jika nilai CR bernilai lebih kecil dari 10\%. Kemudian masing-masing kriteria dapat dihitung bobotnya.

Hasil

perbandingan berpasangan, menunjukan kriteria paling dominan yang menjadi pertimbangan pemilihan jasa logistik adalah kriteria Reliability (keandalan), dengan bobot $40.40 \%$ diikuti dengan criteria cost dengan bobot $22.60 \%$. Sedangkan kriteria yang paling kurang dipertimbangkan oleh responden dalam menentukan penyedia jasa terbaik adalah kriteria services, dengan bobot 18,20\%, berbeda tipis dengan kriteria convenience dengan bobot $18.90 \%$. Nilai pembobotan kriteria pengguna jasa logistik ditampilkan pada Tabel 2.

Tabel 2. Preferensi Pengguna jasa terhadap seluruh kriteria level 1

\begin{tabular}{|r|l|c|c|}
\hline \multicolumn{2}{|c|}{ Kriteria } & Bobot & Peringkat \\
\hline 1 & Reliability & $40.40 \%$ & 1 \\
\hline 2 & Convinience & $18.90 \%$ & 3 \\
\hline 3 & Services & $18.20 \%$ & 4 \\
\hline 4 & Cost & $22.60 \%$ & 2 \\
\hline
\end{tabular}

Hasil tersebut menunjukan bahwa para pengguna jasa logistik sangat mementingkan keandalan perusahaan jasa logistik dalam menjalankan proses pengiriman barang. Hal ini disebabkan nilai kepercayaan pelanggan adalah faktor utama untuk dapat bersaing dalam bisnis logistik. Pelanggan akan membayar sedikit lebih mahal untuk mendapatkan keyakinan bahwa perusahaan jasa logistik yang dipilihnya dapat diandalkan untuk mengantarkan paket kirimannya.

\section{Preferensi pengguna pada kriteria tingkat 2 - Reliability}

Berdasarkan kriteria yang diajukan dalam kuesioner, perbandingan berpasangan untuk tingkatan kedua pada kriteria Reliability disajikan pada Tabel 3 dan hasil pembobotan untuk sub-kriteria pembobotan disajikan pada Tabel 4.

Tabel 3. Matriks Perbandingan berpasangan kriteria Reliability 


\begin{tabular}{|c|c|c|c|}
\hline & On-time & Akurasi & Keutuhan \\
\hline On-time & $\mathbf{1}$ & 0.89 & 1.99 \\
\hline Akurasi & 1.13 & $\mathbf{1}$ & 2.02 \\
\hline Keutuhan & 0.5 & 0.49 & $\mathbf{1}$ \\
\hline
\end{tabular}

Berdasarkan matriks berpasangan, dapat diperoleh nilai Eigen value dan Consistency Index (CI) untuk mengetahui Consistensy Ratio (CR) dari analisis perbandingan. Eigen Value pada perbandingan berpasangan untuk kriteria Reliability sebesar 3.02. Jumlah kriteria pada tingkatan kedua kriteria reliability berjumlah 3 kriteria, maka nilai RC adalah 0.58. Perhitungan CI dan CR sebagai berikut:

$$
\begin{gathered}
C I=\frac{(\lambda \max -\mathrm{n})}{n-1}=\frac{(3.02-3)}{2} \\
=0.01 \\
C R=\frac{C I}{R C}=\frac{0.01}{0.58}=0.0172
\end{gathered}
$$

Nilai CR adalah $1,72 \%$, hal ini menandakan bahwa matriks perhitungan konsisten dan valid. Kemudian masing-masing subkriteria pada Reliability dapat dihitung bobotnya. Hasil pengolahan data pada Tabel 4 menunjukan bahwa pada kriteria Reliability, faktor utama yang menjadi pertimbangan adalah kemampuan perusahaan jasa logistik dalam mengirimkan paket/barang kiriman kepada penerima (tujuan) secara akurat.

Bobot kriteria akurasi sedikit lebih unggul dibandingkan dengan kriteria on-time. Sedangkan, bobot paling rendah ditunjukan oleh kriteria keutuhan. Rendahnya kriteria keutuhan, disebabkan sebagian besar barang/paket yang dikirimkan responden merupakan barang tidak mudah rusak (pakaian, buku, aksesoris, dll) yang dianggap tidak begitu terpengaruh terhadap proses penanganan barang (barang rusak karena terbanting) dibandingkan dengan kriteria on-time dan akurasi.

Tabel 4. Preferensi pengguna jasa terhadap kriteria Reliability

\begin{tabular}{|c|l|c|c|}
\hline \multicolumn{2}{|c|}{ Kriteria } & Bobot & Peringkat \\
\hline 1 & On-time & $38,30 \%$ & 2 \\
\hline 2 & Akurasi & $41,80 \%$ & 1 \\
\hline 3 & Keutuhan & $19,90 \%$ & 3 \\
\hline
\end{tabular}

\section{Preferensi pengguna pada kriteria tingkat 2 - Convenience}

Berdasarkan kriteria yang diajukan dalam kuesioner, perbandingan berpasangan untuk tingkatan kedua pada kriteria Convenience disajikan pada Tabel 5 dan hasil pembobotan untuk subkriteria pembobotan disajikan pada Tabel 6.

Tabel 5. Matriks Perbandingan berpasangan kriteria convenience

\begin{tabular}{|l|c|c|c|}
\hline & $\begin{array}{c}\text { Collecting } \\
\text { Unit }\end{array}$ & $\begin{array}{c}\text { Delivery } \\
\text { Coverage }\end{array}$ & $\begin{array}{c}\text { Operating } \\
\text { Hour }\end{array}$ \\
\hline $\begin{array}{l}\text { Collecting } \\
\text { Unit }\end{array}$ & $\mathbf{1}$ & 1.25 & 3.46 \\
\hline $\begin{array}{l}\text { Delivery } \\
\text { Coverage }\end{array}$ & 0.80 & $\mathbf{1}$ & 3.62 \\
\hline $\begin{array}{l}\text { Operating } \\
\text { Hour }\end{array}$ & 0.29 & 0.28 & $\mathbf{1}$ \\
\hline
\end{tabular}

Berdasarkan matriks berpasangan, dapat diperoleh nilai eigen value dan Consistency Index (CI) untuk mengetahui Consistensy Ratio (CR) dari analisis perbandingan. Eigen Value pada perbandingan berpasangan untuk kriteria Reliability sebesar 3.01. Jumlah kriteria pada tingkatan kedua 
kriteria Reliability adalah 3 kriteria, maka nilai RC adalah 0.58 . Perhitungan CI dan CR adalah sebagai berikut:

$$
\begin{gathered}
C I=\frac{(\lambda \max -\mathrm{n})}{n-1}=\frac{(3.08-3)}{2}=0.04 \\
C R=\frac{C I}{R C}=\frac{0.04}{0.58}=0.0689
\end{gathered}
$$

Nilai CR adalah $6,89 \%$, hal ini menandakan bahwa matriks perhitungan konsisten dan valid. Kemudian masing-masing subkriteria pada Reliability dapat dihitung bobotnya. Hasil pengolahan data pada Tabel 6. menunjukan bahwa pada kriteria Convenience, subkriteria utama yang menjadi pertimbangan adalah jumlah tempat pelayanan penerimaan paket/barang kiriman sebesar $46.70 \%$.

Banyaknya jumlah unit layanan memudahkan pelanggan untuk mengakses unit layanan yang dimiliki perusahaan jasa logistik. Hal ini disebabkan sebagian responden adalah pekerja atau ibu rumah tangga, yang hanya memiliki sedikit waktu untuk mendatangi unit layanan. Bobot wilayah pelayanan pengiriman berada di posisi kedua, karena umumnya responden mengirimkan barang ke wilayah di sekitar Jabodetabek atau kota-kota besar, dimana kota-kota tersebut dilayani oleh hampir seluruh perusahaan jasa logistik. Sementara jam buka layanan unit pelayanan bukan merupakan hal penting yang dipertimbangkan oleh responden dibandingkan dengan faktor lainnya.

Tabel 6. Preferensi pengguna jasa terhadap kriteria convenience

\begin{tabular}{|c|c|c|c|}
\hline \multicolumn{2}{|c|}{ Kritteria } & Bobot & Peringkat \\
\hline 1 & Collecting Unit & $46.70 \%$ & 1 \\
\hline 2 & Delivery Coverage & $41.00 \%$ & 2 \\
\hline 3 & Operating Hour & $12.40 \%$ & 3 \\
\hline
\end{tabular}

\section{Analisa Prioritas Global}

Analisa prioritas global, dilakukan untuk mengetahui peringkat penyedia jasa layanan logistik secara keseluruhan, dengan mempertimbangkan seluruh kriteria. Setelah perhitungan untuk matriks perbandingan pada tingkatan kedua selesai, maka bobot untuk prioritas lokal diperoleh. Prioritas lokal merupakan prioritas responden dalam pemilihan penyedia jasa logistik, berdasarkan masing-masing kriteria (Reliability, Convenience, Services, Cost).

Langkah berikutnya adalah melakukan operasi perkalian antara matriks yang memuat prioritasprioritas lokal dengan bobot tiap kriteria yang diperoleh dari Tabel 4.2. Perhitungan ini dilakukan untuk mendapatkan matriks prioritas global. Prioritas global merupakan prioritas responden dalam pemilihan penyedia jasa logistik, berdasarkan seluruh kriteria (Reliability, Convinience, Services, Cost) hasil perhitungan bobot pada tingkatan pertama.

Perhitungan Matriks prioritas global menggunakan bobot-bobot dari tiap sub kriteria yang didapat dari matriks normalisasi pada matriks perbandingan berpasangan. Kemudian dilakukan penjumlahan dengan metode simple additive weighted, cara ini secara sederhana, menjumlahkan hasil perkaliaan bobot prioritas lokal dengan bobot antar kriterianya. Hasil perhitugan prioritas global, disajikan pada Tabel 7. Urutan 
prioritas dipilih berdasarkan alternative yang memiliki nilai bobot total terbesar diiurutkan sampai alternative dangan nilai bobot total terkecil.

Tabel 7 Prioritas Global penyedia jasa logistik

\begin{tabular}{|r|r|r|r|r|r|}
\hline Alternatif & Reliability & Convenience & Services & \multicolumn{1}{c|}{ Cost } & $\begin{array}{c}\text { Priori- } \\
\text { tas } \\
\text { Wlobal }\end{array}$ \\
\hline JNE & 0.3828 & 0.4922 & 0.4543 & 0.2732 & 1 \\
\hline TIKI & 0.3367 & 0.3030 & 0.3509 & 0.2324 & 2 \\
\hline POS & 0.2805 & 0.2048 & 0.1924 & 0.4945 & 3 \\
\hline
\end{tabular}

Tabel 7, menunjukan bahwa, secara keseluruhan responden menilai bahwa JNE unggul pada seluruh kriteria yang digunakan dalam survey ini. JNE memiliki bobot tertinggi, sebesar 39.15\%, lebih unggul dibandingkan dengan TIKI dan POS. Sedangkan dua pesaingnya memiliki nilai bobot akumulasi yang berbeda tipis, dimana TIKI hanya unggul sebesar $1.03 \%$ dibandingkan dengan bobot PT. POS.

Berdasarkan hasil pembobotan pada Tabel 5, diketahui bahwa secara keseluruhan, responden mengganggap penyedia jasa kurir terbaik, diatara alternatif yang tersedia adalah JNE. Bobot penyedia jasa kurir tidak berbeda signifikan antara TIKI dan POS. Sedangkan preferensi terhadap JNE jauh lebih tinggi dibandingkan dua pesaingnya. Hal ini terjadi karena bobot terbesar untuk kriteria berasal adalah Reliability, dimana pada kriteria ini, JNE memiliki nilai lebih tinggi. DAFTAR PUSTAKA

Adriana, Y., \& TIP, T. D. (2012). Supplier Evaluation And Selection In Agroindustrial Supply Chain Management Of Guava Fruit Juice
Sedangkan walaupun POS unggul pada kriteria Cost, namun secara global bobot kriterianya, masih jauh lebih rendah dibandingkan dengan Reliability.

\section{KESIMPULAN}

Berdasarkan penelitian yang telah dilakukan, diketahui bahwa:Kriteria yang diutamakan oleh responden dalam memilih enyedia pelayanan logistik adalah Reliability dengan bobot 0.4018 , diikuti kriteria Cost, dengan bobot 0.2275 , kemudian kriteria Convenience dengan bobot 0.1886 , dan terakhir adalah kriteria Services dengan bobot 0.1820.Berdasarkan priorotas global, diperoleh bahwa JNE memiliki nilai tertinggi sebesar $39.15 \%$ lebih unggul dibandingkan TIKI dan POS. Hal ini menujukan bahwa penyedia jasa logistik yang paling unggul menurut responden adalah JNE.

Berdasarkan kesimpulan diatas, dapat disarankan kepada perusahaan penyedia jasa logistik untuk lebih memperhatikan faktor Reliability dan Cost dalam menjalankan usahanya. Untuk faktor Reliability dapat dilakukan melalui usaha untuk meningkatkan kepercayaan pelanggan. Kepercayaan pelanggan dapat ditingkatkan salah satunya dengan meminimalisir keluhan pelanggan terhadap jasa pengiriman. Sedangkan untuk faktor cost dapat dilakukan dengan menekan harga pelayanan kepada konsumen.

(Case Study Guava Fruit Juice Industry PT XYZ, Subang, Jawa Barat). Jurnal Teknologi Industri Pertanian, 22(2). 
Chan, F. T., Chan, H. K., Lau, H. C., \& Ip, R. W. (2006). An AHP approach in benchmarking logistics performance of the postal industry. Benchmarking: An International Journal, 13(6), 636661.

Chopra, S., \& Meindl, P. (2004). Supply Chain Management, Prentice-Hall. New Jersey.

Falsini, D., Fondi, F., \& Schiraldi, M. M. (2012). A logistics provider evaluation and selection methodology based on AHP, DEA and linear programming integration. International Journal Of Production Research, 50(17), 4822-4829.

Guitouni, A., \& Martel, J. M. (1998). Tentative guidelines to help choosing an appropriate MCDA method. European Journal of Operational Research, 109(2), 501-521.

Kalogistik. 2013, Laporan Tahunan PT. Kereta Api Logistik Tahun 2013. Jakarta.

Maniya, K., \& Bhatt, M. G. (2010). A selection of material using a novel type decision-making method: Preference selection index method. Materials \& Design, 31(4), 17851789.

Padmowati, R. D. L. E., \& Parahyangan, J. T. I. K. (2009). Pengukuran Index Konsistensi Dalam proses Pengambilan Keputusan Menggunakan Metode AHP. In Jurnal Seminar Nasional Informatika. Universitas Katolik Parahyangan
Perpres, 2012. Peraturan Presiden Republik Indonesia Nomor 26 Tahun 2012. Tentang Cetak Biru Pengembangan Sistem Logistik Nasional. Jakarta

Rahmadani, J. M., \& Ciptomulyono, U. (2011). Integrasi metode analytical hierarchy process (AHP) dan goal programming dalam optimasi pemilihan alternatif pemasok di PT XYZ Indonesia Power. Program Studi Magister Manajemen Teknologi Bidang Keahlian Manajemen Industri. Institut Teknologi Sepuluh Nopember. Surabaya.

Sadiq S, M., Bhatnagar, R., \& Sohal, A. S. (2006). A comparative study on the use of third party logistics services by Singaporean and Malaysian firms. International Journal of Physical Distribution \& Logistics Management, 36(9), 690-701.

Sevkli, Mehmet. (2010). An application of the fuzzy ELECTRE method for supplier selection. International Journal Of Production Research 48, no. 12: 3393-3405. Business Source Elite

Stock, J. R., \& Lambert, D. M. (2001). Strategic logistics management (Vol. 4). Boston, MA: McGraw-Hill/Irwin.

Ting, S. C., \& Cho, D. I. (2008). An integrated approach for supplier selection and purchasing decisions. Supply Chain Management: An International Journal, 13(2), 116-127. 